\title{
Recent patent applications in stem cell reprogramming
}

\begin{tabular}{ll} 
Patent number & Description \\
\hline US8759098B2 & $\begin{array}{l}\text { Reprogramming a population of tissue stem cells, comprising } \\
\text { contacting a population of tissue stem cells with xanthine in a } \\
\text { culture medium; culturing the population in the culture medium } \\
\text { to expand the number of tissue stem cells; and culturing the } \\
\text { population in a medium capable of supporting the maintenance } \\
\text { of pluripotent cells or reprogrammed cells, where the medium is } \\
\text { different from that of the culture medium. }\end{array}$ \\
\hline US20140170752A1 & $\begin{array}{l}\text { A transformation construct comprising a vector backbone includin } \\
\text { several reprogramming factors. Each reprogramming factor is } \\
\text { under the control of a separate promoter. The vector backbone is } \\
\text { contained in an adenovirus particle. }\end{array}$ \\
\hline US8748179B2 & $\begin{array}{l}\text { A method for generating induced pluripotent stem (iPS) cells } \\
\text { involving transducing reprogramming factors that induce somatic } \\
\text { cells derived from oral mucous membrane into pluripotent stem } \\
\text { cells. }\end{array}$ \\
& $\begin{array}{l}\text { Detecting embryonic stem (ES) cells or iPS cells in a sample, } \\
\text { comprising providing a sample potentially containing ES or iPS } \\
\text { cells; providing a rosamine compound that selectively produces } \\
\text { fluorescent signals for ES or iPS cells; contacting the sample with } \\
\text { the compound; and detecting the presence of the ES or iPS cells } \\
\text { based on fluorescent signals emitted by the sample following the } \\
\text { contacting. }\end{array}$
\end{tabular}

US20140120621A1 An in vitro method for the production of iPS cells from somatic cells, comprising reprogramming a somatic cell by introducing a nucleic acid minimally encoding octamer-binding transcription factor 3/4 (Oct3/4) and optionally additionally encoding sexdetermining region $\mathrm{Y}$ (SRY)-box 2 (Sox2) and c-Myc into the somatic cell; contacting the somatic cell with an inhibitor of tumor growth factor- $\beta$ (TGF- $\beta$ ) receptor activity; and isolating the iPS cell.

US8709805B2

Producing a canine iPS cell, comprising bringing a canine somati cell and a nuclear reprogramming factor into contact with each other and culturing the cell in a medium containing at least one substance including a mitogen-activated protein kinase inhibitor, an activin receptor-like kinase inhibitor, a glycogen synthase kinase inhibitor, an L-type calcium channel agonist and a DNA methylation inhibitor or a leukemia inhibitory factor.

W02014053082A1 Preparing iPS cells from somatic cells, involving transfecting isolated somatic cells to express octamer-binding protein $3 / 4$ (Oct3/4), sex-determining region $Y(S R Y)$-box 2 (Sox2), and poly [adenosine diphosphate (ADP)-ribose] polymerase 1 (PARP-1), and culturing the transfected somatic cells under appropriate conditions for converting the somatic cells or at least a subset of the population of somatic cells into iPS cells and maintaining pluripotency and self-renewal ability.

US20140051600A1 Generating stem cells having a reduced rate of cellular aging, involving collecting a cell sample from a validated supercentenarian individual, reprogramming cells from the cell sample into iPS cells, identifying supercentenarian (sc) iPS cells which exhibit telomere-length resetting; deriving the stem cells that exhibit telomere length resetting from the sciPS cells, and generating stem cells having a reduced rate of cellular aging as compared to stem cells from iPS cells from a nonsupercentenarian donor.

US20140051171A1 Producing neural stem cells, comprising providing somatic cells; reprogramming the somatic cells to neural stem cells by introducing at least two genes selected from the group of Bmi1, Sox2, Mash 1, Sox11, Emx2, Foxg1 and Pax6; and inducing the reprogramming with growth factors and a small molecule.

US20140024119A1 A reprogramming-inducing composition comprising the Rex 1 protein or a nucleic acid molecule encoding the Rex 1 protein for producing iPS cells from somatic cells or nonembryonic cells through a reprogramming process, and a method for producing iPS cells by using Rex1.

\section{Assignee}

Boston Biomedical

Sherley JL
Research Institute (Watertown, MA, USA),

Priority Publication

Inventor application date date

Sherley JL

$12 / 4 / 2009$

$6 / 24 / 2014$

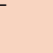

University of Utah Research Foundation (Salt Lake City, UT, USA)

Osaka University

(Osaka, Japan),

Egusa $\mathrm{H}$, Kayashima $\mathrm{H}$, Yatani $\mathrm{H}$

New York University

(New York), National

University of Singapore Yun SW, Park SJ,

Pulst SM,

2/14/2011

$6 / 19 / 2014$

(Singapore), Park SJ, Ahn Y-H

Yun SW, Ahn Y-H,

$\mathrm{Ha} \mathrm{HH}$, Chang Y-T,

Agency for Science

Technology \& Research

(Singapore), Kang NY

General Hospital Corp.

(Boston)

Hochedlinger $\mathrm{K}$

Stadtfeld M

$8 / 25 / 2008$

$5 / 1 / 2014$

Shimada $\mathrm{H}$,

Nakamura T,

Nakamura T,

$8 / 7 / 2009$

$4 / 29 / 2014$

Kyoto University

(Kyoto, Japan)

Shimada $\mathrm{H}$

$8 / 31 / 2009 \quad 6 / 10 / 2014$

Kayashima $\mathrm{H}$

$8 / 24 / 2010 \quad 5 / 27 / 2014$

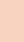

$\begin{array}{ll}\text { Chiou S-H } & \text { Chiou S-H, } \\ & \text { Chien Y, } \\ & \text { Chiou G-Y, } \\ & \text { Yang Y-P }\end{array}$

10/1/2012 4/10/2014

Chiou G-Y,

\begin{tabular}{llll}
$\begin{array}{l}\text { Mandala Biosciences } \\
\text { (San Diego), }\end{array}$ & Larocca DJ & $8 / 16 / 2012$ & $2 / 20 / 2014$ \\
Larocca DJ & & & \\
& & & \\
& & & \\
& & & \\
$\begin{array}{l}\text { Hoffmann-La Roche } \\
\text { (Nutley, NJ, USA) }\end{array}$ & $\begin{array}{l}\text { Christensen K, } \\
\text { Graf M, } \\
\text { lacone R, }\end{array}$ & & \\
& Jagasia R & & \\
& & & \\
$\begin{array}{l}\text { Korea Research } \\
\text { Institute of Bioscience } \\
\text { \& Biotechnology } \\
\text { (Yuseong-gu, S. Korea), } \\
\text { Cho YS, Son MY }\end{array}$ & & \\
\hline
\end{tabular}

Source: Thomson Scientific Search Service. The status of each application is slightly different from country to country. For further details, contact Thomson Reuters (Search Service), 1925 Ballenger Avenue, Suite 400, Alexandria, VA 22314, USA. Tel: 1 (800) 337-9368 (http://thomsonreuters.com/). 